\title{
Student Employment During the Transition to College in the United States
}

\author{
Robert Bozick
}

February 2008 


\section{About the Author}

Robert Bozick, PhD, is an education research scientist in RTI's Education Studies Division and is based in RTI's Washington, DC, regional office.
RTI Press publication RR-0001-0802

This PDF document was made available from www.rti.org as a public service of RTI International. More information about RTI Press can be found at http://www.rti.org/rtipress.

RTI International is an independent, nonprofit research organization dedicated to improving the human condition by turning knowledge into practice. The RTI Press mission is to disseminate information about RTI research, analytic tools, and technical expertise to a national and international audience.

\section{Suggested Citation}

Bozick, R. (2008). Student Employment During the Transition to College in the United States. RTI Press publication No. RR-0001-0802. Research Triangle Park, NC: RTI International. Retrieved [date] from http://www.rti.org/rtipress.

C)2008 Research Triangle Institute. RTI International is a trade name of Research Triangle Institute.

All rights reserved. Please note that this document is copyrighted and credit must be provided to the authors and source of the document when you quote from it. You must not sell the document or make a profit from reproducing it.

doi:10.3768/rtipress.2008.rr.0001.0802

www.rti.org/rtipress 


\section{Student Employment During the Transition to College in the United States}

\author{
Robert Bozick
}

\section{Abstract}

In this paper, I use a nationally representative sample of American high school seniors in 1992 to examine change and stability in the employment patterns of youth as they make the transition from high school to college. Students with weak attachments to the labor force in high school tend to remain unemployed during the first year of college. Conversely, students who work in moderation while in high school have the highest odds of enrolling in college and working while doing so. Compared with their nonworking peers, student workers enter college with lower grades and test scores but are equally engaged in school. Socioeconomic factors have little bearing on high school employment, but they are strongly related to postsecondary employment: students who work during the first year of college have fewer socioeconomic resources than nonworking students. The findings highlight the intersection of school and work in young adulthood and its importance when studying the transition from high school to college among contemporary American youth.

\section{Contents \\ Introduction \\ Enrollment-Employment Linkages in the Early Life Course \\ The Context of Employment and Postsecondary Enrollment 4 \\ Research Questions and Hypotheses 5 \\ Methods 6 \\ Data 6 \\ Measures of Key Concepts \\ Academic Performance, Academic Engagement, and Socioeconomic Support 8 Demographic Characteristics 9 Statistical Procedures 9 \\ Results 9 \\ Do Patterns of Adolescent Employment Lead to Different Postsecondary Pathways? \\ Are Work Patterns of First-Year College Students Related to Academic Performance, Academic Engagement, and Socioeconomic Support? 11 \\ Discussion 16 \\ Conclusion \\ References \\ Acknowledgments Inside back cover}




\section{Introduction}

With the exception of a few spells (e.g., family leave, unemployment, and extended vacations), a large portion of the adult life course is spent in the labor force. On average, the first forays into the world of work occur during adolescence, while most youth are still enrolled in school. The majority of American youth enter the adult labor force this way, balancing the roles of student and worker as they commute from their homes to school and to work. Youth continually adjust their schedules to the ebbs and flows of the academic calendar and the seasonal demand for certain forms of labor. This is not a new phenomenon to social scientists. In fact, a large literature is devoted to the employment experiences of middle and high school students (Entwisle et al., 2000; Greenberger and Steinberg, 1986; Mortimer, 2003).

Surprisingly, the enthusiasm and rigor with which this issue has been pursued trails off at later stages of schooling. This is unfortunate, as the majority of high school graduates in the United States now go on to college (US Department of Education, 2002) and the majority of college students also hold jobs (US Department of Education, 2003). In other words, the modal postsecondary pathway for American youth is both to go to college and to hold a job. Despite the evolution of student employment and the large number entering adulthood as "student workers," little is known about this transitional period, when youth are stepping out of high school and embarking on their college careers.

In this paper, I take a small step toward filling this void in the literature by examining the linkages between school and work from high school through the first year of college. Specifically, I assess the pattern of employment at both stages of schooling and document the socioeconomic, academic, and demographic correlates of these patterns. First, I discuss the development of the student worker as commonly accepted in the sociological literature. Next, I describe the economic, organizational, life course, and social changes that occur during the transition to college, as well as their implications for investment in paid work. I then trace the employment patterns of a cohort of high school seniors in 1992. Finally, I discuss the results in the context of changes in the educational life course.

\section{Enrollment-Employment Linkages in the Early Life Course}

Most contemporary research on youth employment was spurred by a series of blue-ribbon commissions in the 1970s that were pessimistic about the relationship between schools and the larger economy. At the time, experts believed that schooling in the modern era was an isolating experience, removed from the world of work and removed, too, from the experiences of everyday life that help prepare youth for the challenges that await them in adulthood (see, for example, the President's Science Advisory Committee, 1974), including learning practical skills that are valued in the workplace. Part-time employment during high school, at its best, can help foster timemanagement skills, personal accountability, proficiency in performing tasks, interpersonal skills, and the ability to meet the expectations of supervisors. Young people who lack these skills and knowledge about the work world will find it difficult to establish economic independence from their parents and to become productive citizens and workers. Employment, in these ways, is an important component of adolescent development and is critical in the transition to adulthood.

As mentioned above, obtaining and maintaining employment is a process that begins early in the life course; most youths initiate paid work outside the home around the age of 12 (Mortimer, 2003). These early jobs tend to be freelance jobs such as yard work and babysitting. As youths grow older, they increasingly participate in the formal labor force. By the junior year of high school, 61 percent of students hold paid jobs, and by the senior year, 72 percent of students do (Oettinger, 1999). Across all 4 years of high school, more than 90 percent of students at some point participate in the labor force (Manning, 1990; Steinberg and Cauffman, 1995). Additionally, as youths age, they gradually take on higher-paying jobs that are more complex and require greater skill (Entwisle et al., 2000; Mortimer et al., 1994).

Are students who work different from students who do not work? What factors lead some students to invest in work more heavily than others? Early studies failed to inform these questions, focusing instead on the consequences of working-typically finding 
that high-intensity employment (i.e., working more than 20 hours per week) was associated with poorer academic, developmental, and behavioral outcomes (D’Amico, 1984; Greenberger and Steinberg, 1986; Marsh, 1991). However, whether these outcomes really were consequences of work was unclear.

Does paid work have a direct causal effect on youth outcomes, or is the effect of paid work spurious owing to differential selection to the workforce? In other words, do youth perform poorly in school and/or engage in delinquent behavior because of labor force participation, or do student workers struggle in the classroom and get into trouble before they take on paid work? As concerns grew that pre-existing differences between workers at various levels of intensity might be driving these observed negative relationships, research attention shifted toward understanding the processes that lead students into the workforce.

Jeylan Mortimer has advanced the leading perspective on the development of employment in the early life course (2003). Working from a social psychological framework, she contends that how youth structure their time follows from how they view their future "possible selves." In other words, the types of activities in which students elect to participate, such as hanging out with friends, working at a job, or playing on a school sports team, reflect their expectations for the roles they expect to hold in the future. Students who anticipate higher education as a part of their future choose activities that will enable this possibility; noncollege-oriented students channel their energies in other directions.

These future orientations, Mortimer posits, are shaped by students' intellectual, dispositional, and socioeconomic resources. Students who perform well in school stay engaged in the learning process and focus on their studies. These education-oriented students feel that higher levels of education are attainable and structure their time so as to optimize their investments in schooling. Conversely, students who struggle academically eventually see higher levels of education as less and less a real possibility. These students become disengaged and put little effort into schoolwork because they see no payoff from this type of investment.
Socioeconomic resources also play a role in shaping student orientations: Students from advantaged backgrounds see few barriers to higher education, whereas students from disadvantaged backgrounds often believe that college is out of their reach. Therefore, high-socioeconomic-status (SES) students will allocate more of their time to school-related activities than low-SES students.

Of importance for my study is that these future orientations also shape student involvement in paid work. Students with strong academic skills, who are engaged in their studies, and who have ample socioeconomic resources tend to see higher education as a part of their future. Toward that end, these students likely manage their time to stay focused on school. In other words, they limit their involvement in the labor force so that they can complete school assignments, devote ample time toward studying, and participate in school-sponsored extracurricular activities. By contrast, students who are behind academically, who are disengaged from school, and who have limited socioeconomic resources will invest more in their paid jobs because what they foresee following high school is the labor market, not college.

Mortimer (2003) tested these ideas with data from the Youth Development Study (YDS), a panel study of approximately 1,000 students who enrolled in the ninth grade in the St. Paul, Minnesota, school district in the 1987-1988 school year. The YDS followed this cohort throughout their high school careers and beyond. Mortimer studied the relationship between patterns of involvement in paid work throughout high school and student characteristics measured in the ninth grade. Her analysis revealed that students who worked for the bulk of the school year at high levels of intensity initially had lower grade point averages and lower intrinsic motivation toward school than their peers who worked in moderation. Additionally, students with highly educated parents were more likely to limit their participation in paid work than students with less-educated parents. Compared with students with a steady but limited investment in work, nonworking students had lower intrinsic motivation to school and had higher levels of problem behavior in the ninth grade. According to these findings, students' intellectual, dispositional, 
and socioeconomic resources bear heavily on their enrollment-employment trajectories.

Additional research using national data has supported the patterns found in St. Paul, Minnesota. In their analysis of the National Education Longitudinal Study of 1988 (NELS:88), Warren et al. (2000) found that students who worked at low levels of intensity in the 10th grade came from more advantaged families and had higher grades in the 8th grade than both nonworking students and students who worked at high levels of intensity. Also using NELS:88, Schoenhals et al. (1998) modeled weekly hours worked in the 10th grade as a function of student characteristics measured in the 8th grade. They found that students with college-educated parents, high grades and standardized test scores, and low levels of school disengagement work fewer hours than their counterparts with less-educated parents, lower grades and standardized test scores, and higher levels of school disengagement.

More recent analyses based on a sample of 12 - and 13-year-old adolescents from the National Longitudinal Survey of Youth 1997 also find that students' orientations toward schooling shape their early investments in the labor force: students who have been suspended from school, who spend no time on their homework, and whose parents failed to finish high school work more hours per week than students who have never been suspended, who devote time to their homework, and have highly educated parents (Huang et al., 2001).

Taken together, the available evidence depicts a pattern of divergent enrollment-employment trajectories among high school students. Students with the most potential for success in school invest in paid work in moderation so that they can be well rounded, while allowing adequate time for education-related activities. Those who struggle in school and have low levels of socioeconomic support turn to paid work as a source of fulfillment and achievement, as they most likely will enter the labor force following high school. The story trails off from there, however. Do these divergent pathways continue on into the postsecondary years or do new patterns of employment emerge? My study attempts to answer this question by examining student involvement in the labor force while pursuing a postsecondary degree.

\section{The Context of Employment and Postsecondary Enrollment}

Because most of the research on youth labor force participation focuses on the work experiences of high school students, very little is known about the relationship between work and school at the postsecondary level. Although it is tempting to apply the same perspectives used in inquiries about adolescent workers to college students, the context of college is very different from that of high school in ways that preclude straightforward extrapolation.

The most relevant differences involve economic, organizational, life course, and social considerations. First, consider finances: roughly 90 percent of students in kindergarten through 12th grade attend public schools (US Department of Education, 2002). Most public schools provide books, and none charge tuition. There are expenses-supplies, meals, sometimes transportation-but these pale in comparison to the costs associated with college, even low-cost public institutions. For example, in the 2002-2003 school year, the average tuition at a 4 -year public school was $\$ 4,081$, books and supplies were $\$ 786$, and room and board were $\$ 5,327$ (College Board, 2002). Therefore, although paid work in the high school years is typically undertaken for personal consumption, the financial requirements of a college education may make employment an economic necessity rather than a means for acquiring disposable income. Given the greater financial burden of college, the effects of economic resources on paid work might be stronger during the college years.

Second, high school and college have organizational differences. For instance, in high school, students typically adhere to a standard curriculum mandated by the school or the local school board. Students are obliged to take prescribed classes in order to graduate, regardless of their personal interest in the topic. In contrast, college students can choose their own majors and enroll in courses that suit their interests and abilities. In addition to their strict curricular structure, high schools typically require that students be present on school grounds 
Monday through Friday between the hours of 8 a.m. and 3 p.m. Disciplinary actions such as after-school detentions can increase this time obligation. The collegiate schedule, in contrast, is quite open. College students have greater flexibility to create course schedules that are compatible with their jobs, family commitments, and social lives. They can attend part-time and even stop out for a semester without insurmountable administrative obstacles.

With respect to Mortimer's predictions, poorperforming students who make it into college have more flexibility in their scheduling and can structure their lives to better suit their studying styles. On the other hand, academically motivated students who are future-oriented and want to acquire work experience without their coursework suffering can do so with little consequence. Hence, these organizational differences would predict that the relationship between academic preparation and paid work is weaker during the transition to college than in the high school years.

Third, college students are at a different stage in the life course (young adulthood) than high school students (adolescence), and the experience of being both a student and a worker may be drastically different in young adulthood. Compared with high school students, college students are developmentally more mature. Paid work in addition to school attendance is no longer a "new" experience-most have spent some time in the labor force and so may be more adept at juggling the dual demands of their jobs and their coursework. Almost all college students are at least 18 years of age and thus no longer bound by child labor restrictions. More types of jobs are legally available to college students, and fewer restrictions are placed on their hours, tasks, and wages.

Last, the social context of college, particularly at the outset, can be as exciting as it is daunting. Students leaving high school and entering college are undergoing a great deal of stress and anxiety, as the postsecondary social environment is often vastly different than that of high school. Additionally, the transition to college occurs at a pivotal time in young adulthood and is accompanied by many new and foreign experiences: first-year students are often leaving their homes and peer groups for the first time, the institutional bureaucracy of college is confusing and intimidating, and college campuses contain entirely new sets of social norms and relationships. For some students, college is the first time that they are exposed to people from different racial, ethnic, economic, and religious backgrounds. Moreover, the first year of college is often accompanied by elevated levels of anxiety and depression (Furr et al., 2001). These life course and social context differences suggest that documented patterns and correlates of adolescent employment may not hold during the postsecondary years.

\section{Research Questions and Hypotheses}

Because studies seldom link employment patterns in high school to paid work during the college years, my research provides a fresh look at how employment during the transition to college relates to earlier experiences in school and in the labor force. Below I describe the central research questions and outline my hypotheses.

\section{Do Patterns of Adolescent Employment Contribute to Different Postsecondary Pathways?}

One oft-replicated finding in the literature is that students who accumulate a large amount of work experience in high school achieve lower levels of educational attainment than students who work less intensely (Carr et al., 1996; Mortimer, 2003; Steel, 1991). Therefore, students with the strongest attachments to the labor force during the high school years are likely to have the lowest odds of enrolling in college.

Another consistent finding in the literature is that students who work during high school are less likely than students who do not work to be unemployed post-high school (Meyer and Wise, 1982; Stern and Nakata, 1989; Stevenson, 1978). Although these inquiries do not explicitly consider employment while enrolled in a postsecondary institution, similar trends for first-year college students are likely. Those who worked in high school will have more human capital and workplace skills to offer employers than will their nonworking peers. Also, college students who worked in high school have had experience balancing the 
roles of worker and student. Thus, I predict that high school students who worked at moderate levels will likely enroll in college and maintain their attachments to the labor force, whereas those with no work experience will have the lowest odds of enrolling in and working in college.

\section{Are Working College Students Different from Their Nonworking Counterparts?}

Mortimer's theory of future orientations and time use has been empirically supported with data on the paid work experiences of adolescents. However, whether these patterns hold for labor force participation during the postsecondary years is uncertain. As discussed earlier, the context of college employment is unlike that of high school, and there is reason to suspect that selection-to-work processes may be different at the postsecondary level. The financial burden associated with college enrollment suggests that socioeconomic factors might play a stronger role in shaping the work patterns of first-year college students, and the organizational, life course, and social differences between high school and college may alter the relationship between academic characteristics and student employment.

Additionally, changes in the composition of students at different stages of schooling could affect the correlates of paid work. If those students who work most intensely in high school tend to forgo college, then differences between workers and nonworkers on measures of academic performance, academic engagement, and socioeconomic support will be tempered, if not eliminated, among college students. By contrast, the high rates of return to postsecondary education and the "college-for-all" ethos that pervades the US education system has bolstered the enrollment rates of poorly prepared students in recent years (Rosenbaum, 2001). If a large number of these students become employed during college, then differences between working and nonworking adolescents with respect to ability, academic engagement, and socioeconomic support may hold also for the college-going population. Research in this area has mostly neglected the employment experiences of college students; my analysis will help sort among these possibilities.

\section{Methods}

\section{Data}

To test these hypotheses, I used data from the National Education Longitudinal Study of 1988 (NELS:88), collected by the National Center for Education Statistics (NCES), to link employment patterns in the first year of college with earlier experiences in school and in the labor force. NELS:88 is a nationally representative survey of 24,599 eighth graders in 1988 focusing on the relationships between family, school, and educational performance. NCES resurveyed students in their sophomore year of high school (1990), their senior year of high school (1992), 2 years after on-time graduation (1994), and 8 years after on-time graduation (2000). In addition to the information obtained from students, NCES also interviewed parents, teachers, and school administrators and collected high school and college transcripts, making NELS:88 a rich data set for an exploration of these issues. NELS:88 used a two-stage sampling procedure. In the first stage, 815 public schools and 237 private schools were selected with probabilities proportional to their eighth-grade enrollment. In the second stage, 26 students were randomly sampled from each school on the condition that they did not have serious physical or emotional problems, a mental handicap, or an inability to speak the English language.

NELS:88 lends itself well to my research questions for three key reasons: (1) it contains information on students' paid work experience during high school; (2) it has a variety of measures of academic performance, academic engagement, and socioeconomic support; and (3) it includes a month-bymonth enrollment-employment history for the first couple of years following high school graduation. For this analysis, I restricted the sample to the 11,565 respondents who were sophomores in the 1989-1990 school year, who were members of the 12th-grade senior year class of 1992, and who had completed the 10th grade (1990), 12th grade (1992), and the 2 -year post-high school graduation interviews (1994). I excluded 744 students who lacked complete information on postsecondary enrollment and employment, producing an analytic sample of 10,821 students. 
Differences in samples sizes across analyses result from listwise deletion of respondents with missing data on other variables. I used the appropriate sampling weights provided by NCES to adjust for item nonresponse so that the results presented here generalize to the in-school senior class of 1992. Additionally, I used survey (svy) commands in STATA when conducting tests of significance. These commands use Taylor-series linearization methods to produce correct standard errors for samples that were drawn using a stratified cluster design (StatCorp, 2001).

Below I describe how I operationalized the key concepts for the empirical analysis. The measure of postsecondary employment is taken from the 1994 student interview, when the respondents were approximately 2 years out of high school. Measures of high school work experience, academic performance, academic engagement, and socioeconomic support were constructed from variables taken from the 8th-grade (1988), 10th-grade (1990), and 12th-grade (1992) interviews.

\section{Measures of Key Concepts}

\section{Postsecondary Pathways}

To determine employment patterns during the first year of college, I used information on the date of first postsecondary enrollment along with monthby-month enrollment and employment histories. The NELS:88 postsecondary transcript file includes a measure indicating the month and year that the student first enrolled in a postsecondary institution. For cases missing transcript information, I used the students' self-reported first month and year of postsecondary enrollment. In the 1994 student follow-up interview, respondents were asked to provide a month-by-month employment history and enrollment history from June 1992 to August 1994. For each month, respondents reported whether they were employed and whether they were enrolled. ${ }^{1}$

Using the date of first postsecondary enrollment, along with the enrollment and employment histories,

1 A limitation of NELS:88 is that it lacks a measure of employment intensity during the postsecondary years. Consequently, this analysis focuses only on the proportion of the school year the student worked rather than the number of hours worked weekly.
I created a categorical measure of work experience during the first year of college. College enrollees were defined as those who enrolled during the first 12 months following high school graduation (June 1992 through June 1993). I classified students who enrolled in college after June 1993 as nonenrollees. ${ }^{2}$

To prevent misidentifying students as workers if they ended employment the same month they began enrollment, I classified students as workers only if they reported being both enrolled and employed for at least 2 months during their first enrollment spell. "Enroll and some work" indicates that the students worked at least 2 months during their first enrollment spell. "Steady enrollment and employment" indicates that students were employed all 8 months of their first enrollment spell. Together, the full enrollmentemployment measure includes four categories: no college (32.9 percent), enroll and no work (27.5 percent), enroll and some work (24.7 percent), and steady enrollment and employment (14.9 percent). For simplicity, in some analyses I combined categories to form a dichotomous variable indicating whether enrolled students worked during their first enrollment spell.

\section{High School Employment Patterns}

I used variables from the sophomore- and senioryear interviews to create a measure of employment experience in high school. In the 10th-grade interview, students were asked their employment status and the number of hours they usually work per week. Based on employment during the school year, I classified students as nonworkers $\left(\mathrm{N}_{10}\right)$, lowintensity workers $\left(\mathrm{L}_{10}\right)$, and high-intensity workers $\left(\mathrm{H}_{10}\right)$. Low-intensity workers reported working 20 hours per week or fewer; high-intensity workers reported working more than 20 hours per week.

2 Although there has been considerable growth in the number of adult students attending/returning to college, this analysis focuses only on the on-time postsecondary transitions of recent high school graduates. Off-time/adult students are excluded, as they are more likely to be married or divorced, to have children, and to have already had more postsecondary experiences than traditional college-age students (Bozick and DeLuca, 2005; Jacobs and King, 2002). Additionally, adult students presumably rely less on family resources and parental support than do recent high school graduates. Therefore, their enrollmentemployment patterns are likely governed by different social and economic factors and, thus, their inclusion in this analysis might obscure an understanding of the postsecondary transitions of young adults. 
I constructed this measure only for students who were employed during the school year. I did not consider summer employment because the focus here is on the overlap of the student and worker roles. Using a similar question from the 12th-grade interview, I classified student employment during the school year with the same distinctions: nonworkers $\left(\mathrm{N}_{12}\right)$, low-intensity workers $\left(\mathrm{L}_{12}\right)$, and high-intensity workers $\left(\mathrm{H}_{12}\right)$. I excluded students who were not enrolled at the time of the 10th- or 12th-grade interviews, as they lack information on the joint roles of student and worker. ${ }^{3}$

Using these two measures, I created a seven-category measure of employment patterns in high school: nonworkers $\left(\mathrm{N}_{10}, \mathrm{~N}_{12}\right)$, late low-intensity workers $\left(\mathrm{N}_{10}, \mathrm{~L}_{12}\right)$, late high-intensity workers $\left(\mathrm{N}_{10}, \mathrm{H}_{12}\right)$, steady low-intensity workers $\left(\mathrm{L}_{10}, \mathrm{~L}_{12}\right)$, mixedintensity workers $\left(\mathrm{H}_{10}, \mathrm{~L}_{12} ; \mathrm{L}_{10}, \mathrm{H}_{12}\right)$, steady highintensity workers $\left(\mathrm{H}_{10}, \mathrm{H}_{12}\right)$, and stop-out workers $\left(\mathrm{L}_{10}, \mathrm{~N}_{12} ; \mathrm{H}_{10}, \mathrm{~N}_{12}\right)$. The construction of this measure and its distribution are shown in Table 1. Nonworkers reported no work experience at either time point. Late low-intensity workers reported no work experience in the 10th grade, but worked 20 hours or fewer per week in the 12th grade. Late high-intensity workers reported no work experience in 10th grade, but worked more than 20 hours per week in the 12th grade. Steady low-intensity workers were employed 20 hours or fewer per week in both grades. Mixedintensity workers reported either working 20 hours per week or fewer in the 10th grade and more than 20 hours per week in the 12th grade or more than 20 hours per week in the 10th grade and less than 20 hours per week in the 12th grade. Steady highintensity workers were employed more than 20 hours per week in both the 10th and 12th grades. Stop-out

\footnotetext{
3 One limitation of NELS:88 is that it does not contain employment information during the 9 th and 11th grades. Although data on paid work in the 9th and 11th grades are not available, NELS:88 does include a question in the 8th-grade interview about employment. This information was not included in the employment trajectory measure for two reasons. First, the question does not differentiate between paid work during the summer and paid work during the school year-a key distinction for this analysis. Second, the response options for the number of hours worked are different due to the age of the students in the 8th grade. As a consequence, defining high- versus low-intensity work in a way that is directly comparable to employment intensity in the high school years is not possible.
}

workers reported working in the 10th grade at any intensity and not working during the 12 th grade.

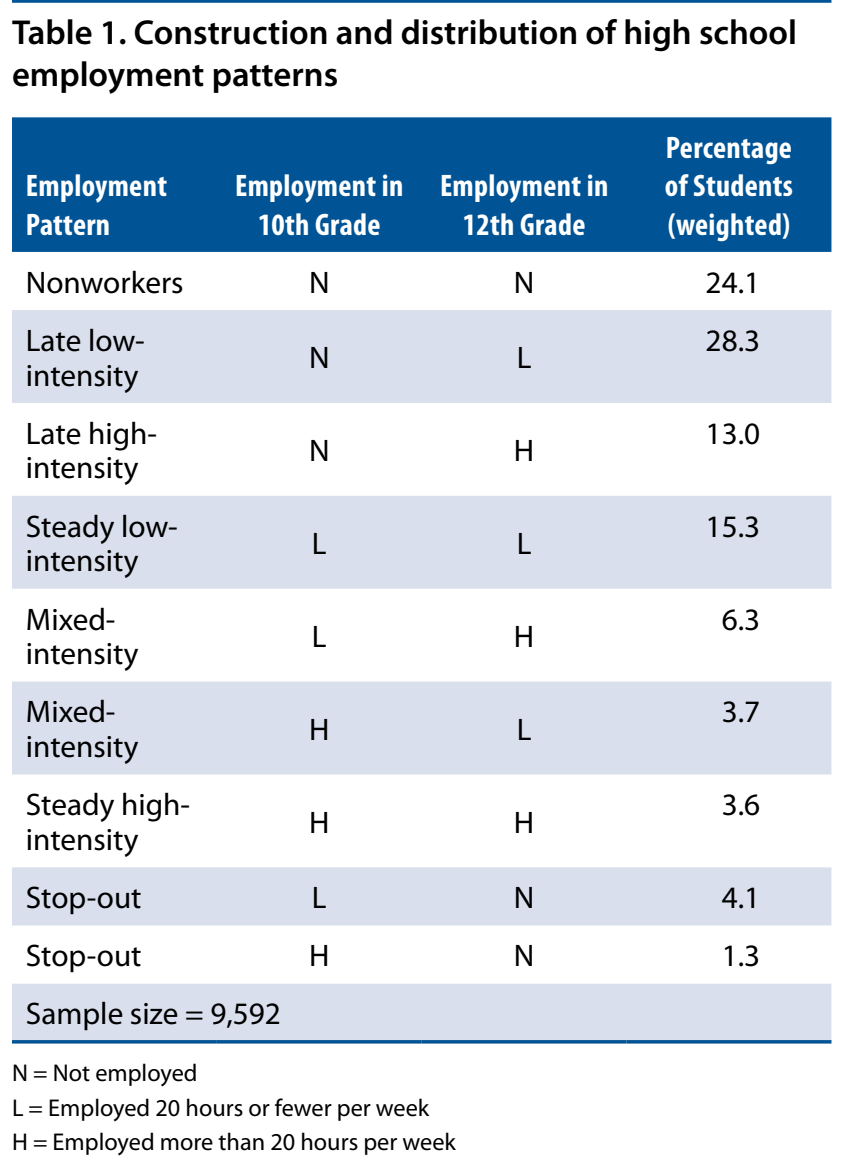

\section{Academic Performance, Academic Engagement, and Socioeconomic Support}

Mortimer's theory of adolescent time use posits that students' cognitive, dispositional, and socioeconomic resources shape their involvement in paid work. To test whether this theory holds for first-year college students, I used measures of academic performance, academic engagement, and socioeconomic support taken from the 8th- and 10th-grade interviews. Measures of academic performance include grade point averages (GPA) and a standardized test score composite based on reading and math tests. Measures of academic engagement include skipping class, tardiness, time spent on homework, time spent on extracurricular activities, and academic preparedness. Measures of socioeconomic support include family income, parental education, and number of siblings.

All student characteristics are taken from the 8th- or 10th-grade interviews and thus reflect the academic 
and socioeconomic condition of students in junior high and the first half of high school. I used measures from these interviews for three reasons. First, they capture early orientations toward schooling and resource levels before most students begin serious planning for life after high school. Second, academic and socioeconomic characteristics concurrent with the first year of college are not available. Third, the use of the earliest measures allows for direct comparisons across all three panels. In Appendix A, I describe the construction of these measures in detail.

\section{Demographic Characteristics}

I also compared postsecondary pathways by demographic characteristics. Past research has shown that in high school, males are more likely than females to hold jobs and that minority students are less likely to obtain employment than comparable white students (D’Amico, 1984; Entwisle et al., 1999; Keithly and Deseran, 1995). Therefore I include measures of sex and race-ethnicity of the student to see if these patterns persist once students enter college. Raceethnicity is represented by a categorical variable that includes the following categories: Asian/Pacific Islander, Hispanic, black non-Hispanic, white nonHispanic, and Native American/other.

\section{Statistical Procedures}

To evaluate the relationship between patterns of paid work in high school and paid work during the transition to college, I cross-tabulated the high school employment measure by the postsecondary employment measure and calculated the odds of different postsecondary enrollment-employment pathways for each high school employment pattern. Odds were calculated as $\pi_{1} / \pi_{2}$, where $\pi_{1}$ is the proportion of students in a given high school employment category following a specific postsecondary pathway and $\pi_{2}$ is the proportion of students in the same high school employment category following an alternative postsecondary pathway.

To test whether differences between working and nonworking high school students extend into the postsecondary years, I calculated the mean/ proportion for every student characteristic by employment status in the 10th grade, 12 th grade, and first year of college. I then conducted Wald tests to assess whether working students are significantly different from their nonworking counterparts at each grade level.

Finally, I conducted a one-way analysis of variance (ANOVA) for each student characteristic across categories of the postsecondary pathway measure. I used a Bonferroni multiple comparison test to assess which comparisons were statistically significant. This procedure is akin to conducting multiple $t$ tests, but is preferable in that it reduces the probability of making a Type I error.

\section{Results}

\section{Do Patterns of Adolescent Employment Lead to Different Postsecondary Pathways?}

The bivariate relationship between patterns of paid work in high school and paid work during the transition to college is shown in Table 2 . The chisquare statistic indicates that patterns of labor force participation during the first year of college are significantly associated with patterns of paid work in the high school years. Students who worked at the highest levels of intensity were the least likely to attend college, while those who worked at moderate levels of intensity were the most likely to attend college. For example, 57.9 percent of those who worked more than 20 hours per week in the 10th and 12th grades did not enroll in college. Those who were able to maintain a moderate balance of the roles of student and worker during the high school years had the smoothest transition into higher education: 78.3 percent of those who worked 20 hours per week or fewer in both the 10th and 12th grades enrolled in college, the highest enrollment rate of any of the student worker groups.

This pattern suggests that employment in moderation during the high school years sets the stage for later attainment. This is consistent with past research that finds that those who work at moderate levels of intensity in high school are the most likely to acquire postsecondary education and that those who work at the highest levels of intensity in high school are the least likely to do so (Mortimer, 2003; Staff and Mortimer, 2007; Steel, 1991). 
Table 2. Postsecondary pathways by high school employment patterns

\begin{tabular}{|c|c|c|c|c|c|c|c|c|}
\hline \multirow[b]{2}{*}{$\begin{array}{l}\text { Postsecondary } \\
\text { Pathways }\end{array}$} & \multicolumn{8}{|c|}{ High School Employment Patterns } \\
\hline & Nonworkers & $\begin{array}{c}\text { Late } \\
\text { Low- } \\
\text { Intensity }\end{array}$ & $\begin{array}{c}\text { Late } \\
\text { High- } \\
\text { Intensity }\end{array}$ & $\begin{array}{c}\text { Steady } \\
\text { Low- } \\
\text { Intensity }\end{array}$ & $\begin{array}{l}\text { Mixed- } \\
\text { Intensity }\end{array}$ & $\begin{array}{c}\text { Steady } \\
\text { High- } \\
\text { Intensity }\end{array}$ & Stop-Out & Total \\
\hline No college & 31.4 & 24.4 & 44.0 & 21.7 & 39.0 & 57.9 & 38.2 & 31.7 \\
\hline Enroll and not work & 40.2 & 28.8 & 19.2 & 23.8 & 17.0 & 6.9 & 30.6 & 27.6 \\
\hline Enroll and some work & 19.5 & 29.9 & 22.2 & 33.8 & 23.7 & 18.0 & 18.1 & 25.3 \\
\hline $\begin{array}{l}\text { Steady enrollment } \\
\text { and employment }\end{array}$ & 8.9 & 16.9 & 14.6 & 20.7 & 20.3 & 17.2 & 13.1 & 15.4 \\
\hline $\mathrm{N}$ & 2,494 & 2,710 & 1,212 & 1,398 & 924 & 319 & 535 & 9,592 \\
\hline
\end{tabular}

$\chi^{2}=740, d f=18, \mathrm{p}<.01$

The paid work experiences of those who went on to college paralleled their earlier work histories. Students who had worked in high school were likely to hold jobs; those who had not been employed in high school tended to remain out of the labor force while in college. For example, 27.6 percent of the entire sample enrolled in college but did not work, while 40.2 percent of nonworkers in high school enrolled in college but did not work. Conversely, those who had worked 20 or fewer hours per week in their sophomore and senior years were most likely to work during their freshman year of college. More than half of these students ( 54.5 percent) enrolled in college and maintained involvement in the labor force.

To get a better sense of how employment in high school is connected to employment during the transition to college, I calculated the odds of different postsecondary enrollment-employment pathways for each high school employment pattern (Table 3). This analysis combined the "enroll and some work" category with the "steady enrollment and employment" category to form a single measure of employment status during the first year of college.

The first column of Table 3 shows the odds that a specific high school work pattern relates to working during the first year of college relative to not working during the first year of college. For example, the proportion of nonworking high school students attending college and working $\left(\pi_{\text {enroll and work }}\right)$ is 0.284 , and the proportion of nonworking high school students attending college and not working
Table 3. Odds of different postsecondary pathways by high school employment patterns

\begin{tabular}{lcc|}
$\begin{array}{l}\text { High School } \\
\text { Employment Patterns }\end{array}$ & $\begin{array}{c}\text { Enroll and Work vs. } \\
\text { Enroll and Not Work }\end{array}$ & $\begin{array}{c}\text { Enroll and Work vs. } \\
\text { Not Enroll }\end{array}$ \\
\hline Nonworkers & 0.71 & 0.91 \\
\hline Late low-intensity & 1.63 & 1.92 \\
\hline Late high-intensity & 1.92 & 0.84 \\
\hline Steady low-intensity & 2.29 & 2.51 \\
\hline Mixed-intensity & 2.59 & 1.13 \\
\hline $\begin{array}{l}\text { Steady high- } \\
\text { intensity }\end{array}$ & 5.10 & 0.61 \\
\hline Stop-out & 1.02 & 0.82 \\
\hline
\end{tabular}

Note: Postsecondary pathways indicate enrollment and employment during the first year of college.

( $\left.\pi_{\text {enroll and not work }}\right)$ is 0.402 . The odds are calculated as $0.284 / 0.402=0.71$.

The odds in Table 3 show that students who did not work in high school are more likely to not work while enrolled than to be student workers. The relationship between employment intensity in high school and employment in the first year of college appears to be linear. The more the student worked in high school, the higher the odds of postsecondary employment. Students who worked at the highest levels of intensity in both the 10th and 12th grades have the highest odds of postsecondary employment. These students are more than five times as likely to hold jobs if they attend college than they are to focus solely on their schoolwork.

The odds in the second column highlight which employment patterns in high school differentiate 
between working college students and nonenrollees. Students who did not work while in high school were more likely not to enroll in college than to take on the joint roles of student and worker. Students who worked at low levels of intensity in high school-late low-intensity, steady low-intensity, and mixed-intensity-had higher odds of becoming working college students than forgoing college altogether. Students who worked only at high levels of intensity-late high-intensity and steady highintensity-were more likely to forgo college than to become working college students.

Taken together, the findings suggest that patterns of student employment are relatively stable during the transition from high school to college. As in earlier research based on adolescents, the evidence suggests diverging pathways of work and school that extend beyond high school and into the postsecondary years.

In broad strokes, there appear to be three types of high school students. First are students with the weakest attachment to the labor force. These students are less likely to enroll in college than their moderately employed peers. If they do enroll in college, they remain out of the labor force. These students likely are unemployable, face employment barriers, or both. In the high school employment literature, students who do not work are less interested in school, score lower on standardized tests, and get into trouble more often than those who work at moderate levels (Mortimer, 2003; Warren et al., 2000). Therefore, these students may be unmotivated, be slow learners, or have behavioral problemsall factors that may make them undesirable to prospective employers. Nonworkers may also be concentrated in impoverished areas with fewer job openings, or they might face discrimination from employers when they do apply for jobs. Whatever the reason, those isolated from the labor force in high school tend to remain that way if they enter college.

The second type of students is those who maintain a moderate attachment to the labor force while in high school. These students are the most likely to continue their education after graduating from high school. They started their employment careers in high school and in doing so acquired job skills and social contacts with little to no consequence to their school work. Their commitment to both school and work appears to bode well for later educational and occupational attainment: students who worked in moderation during the high school years (steady low and late low) are the most likely to continue on to college. Further, these students are the most likely to continue working in moderation while pursuing a postsecondary degree. Because these students have more job skills and well-rounded resumes to offer employers, they likely have an easier time finding new jobs or maintaining their high school jobs once in college. Thus, working in moderation during high school appears to help to ease the transition to working during college.

Last are students who have a strong attachment to the labor force during high school. These students have the most tenuous transition to college. Although most of these students do not go on to college, if they do enroll, they have the highest odds of working during the first year. This complements and extends Mortimer's perspective. Of the 362 steady highintensity workers, the majority (60.2 percent) did not go on to college. These students likely never seriously envisioned college as a part of their future and instead devoted their energies to working while they were in high school. Given the economic returns and the strong push to at least try college out (Rosenbaum, 2001), that some individuals (39.8 percent) decide to enroll is not surprising. When doing so, they also keep one foot in the labor force in case their experimentation with higher education fails. Other research suggests that this pattern is often the case, as those who work at high levels of intensity during the college years tend to drop out (Bozick, 2007; Ehrenberg and Sherman, 1987).

\section{Are Work Patterns of First-Year College Students Related to Academic Performance, Academic Engagement, and Socioeconomic Support?}

If labor force participation in the first year of college is influenced by the same factors that lead high school students into the work force, employed college students would be expected to differ from their nonworking peers on measures of academic performance, academic engagement, and socioeconomic support. To test whether differences between working and nonworking high school students extend into the postsecondary years, the 
mean/proportion for every student characteristic by employment status was calculated in the 10th grade, 12 th grade, and first year of college. The results are presented in Table 4. This analysis used all available cases from each NELS: 88 cross-section in the analytic sample: all 10th graders in 1990, all 12th graders in 1992, and all first-year college students in the 19921993 school year who were seniors in 1992. See
Appendix A for more detailed information on the source and coding of the measures shown here.

Between the high school years and the first year of college, the sample decreases owing to the loss of those who did not continue on to postsecondary education. As a result, Table 4 also illustrates whether changes in the composition of those enrolled across

Table 4. Differences between working and nonworking students in academic performance, academic engagement, socioeconomic support, and demographic characteristics in the 10th grade, 12th grade, and first year of college

\begin{tabular}{|c|c|c|c|c|c|c|}
\hline \multirow{2}{*}{$\begin{array}{l}\text { Student Background } \\
\text { Characteristics }\end{array}$} & \multicolumn{2}{|c|}{ 10th Grade Employment } & \multicolumn{2}{|c|}{ 12th Grade Employment } & \multicolumn{2}{|c|}{$\begin{array}{l}\text { First Year of College } \\
\text { Employment }\end{array}$} \\
\hline & No & Yes & No & Yes & No & Yes \\
\hline \multicolumn{7}{|l|}{ Academic Performance } \\
\hline Grade point average & $3.07^{*}$ & 3.01 & 3.04 & 3.05 & $3.28^{* *}$ & 3.16 \\
\hline $\begin{array}{l}\text { Standardized reading and math test } \\
\text { scores }\end{array}$ & 52.12 & 52.38 & $51.59^{*}$ & 52.32 & $55.33^{* *}$ & 53.90 \\
\hline \multicolumn{7}{|l|}{ Academic Engagement } \\
\hline Proportion skipping class & $0.315^{* *}$ & 0.381 & $0.310^{*}$ & 0.343 & 0.283 & 0.307 \\
\hline Proportion tardy & $0.721^{*}$ & 0.753 & $0.711^{*}$ & 0.741 & 0.710 & 0.715 \\
\hline Weekly hours spent on homework & $4.51^{*}$ & 4.27 & 4.58 & 4.34 & $5.28^{* *}$ & 4.79 \\
\hline $\begin{array}{l}\text { Weekly hours spent on extracurricular } \\
\text { activities }\end{array}$ & $3.80^{*}$ & 3.50 & 3.69 & 3.66 & $4.55^{*}$ & 4.15 \\
\hline Academic preparedness scale & $3.29 * *$ & 3.24 & 3.28 & 3.27 & 3.30 & 3.31 \\
\hline \multicolumn{7}{|l|}{ Socioeconomic Support } \\
\hline Family income (natural logarithm) & 10.35 & 10.40 & $10.27^{* *}$ & 10.40 & $10.61^{* *}$ & 10.45 \\
\hline \multicolumn{7}{|l|}{ Parental education } \\
\hline High school or less & 0.259 & 0.270 & $0.281^{*}$ & 0.251 & $0.162^{* *}$ & 0.215 \\
\hline Some college & 0.404 & 0.421 & $0.370^{* *}$ & 0.434 & $0.336^{* *}$ & 0.439 \\
\hline Bachelor's degree & 0.171 & 0.169 & 0.160 & 0.171 & $0.226^{* *}$ & 0.188 \\
\hline Graduate degree & $0.167^{*}$ & 0.141 & $0.188^{* *}$ & 0.144 & $0.277^{* *}$ & 0.159 \\
\hline Number of siblings (natural logarithm) & 0.706 & 0.725 & $0.732^{*}$ & 0.688 & $0.609^{*}$ & 0.662 \\
\hline \multicolumn{7}{|l|}{ Demographic Characteristics } \\
\hline \multicolumn{7}{|l|}{ Sex } \\
\hline Female & $0.521^{*}$ & 0.489 & $0.477^{* *}$ & 0.519 & 0.517 & 0.542 \\
\hline Male & $0.479^{*}$ & 0.511 & $0.523^{* *}$ & 0.481 & 0.483 & 0.458 \\
\hline \multicolumn{7}{|l|}{ Race/ethnicity } \\
\hline Asian/Pacific Islander & $0.045^{*}$ & 0.034 & $0.057^{* *}$ & 0.035 & 0.057 & 0.046 \\
\hline Hispanic & $0.104^{* *}$ & 0.071 & $0.118^{* *}$ & 0.083 & 0.081 & 0.093 \\
\hline Black, non-Hispanic & $0.116^{*}$ & 0.092 & $0.161^{* *}$ & 0.087 & $0.118^{* *}$ & 0.088 \\
\hline White, non-Hispanic & $0.726^{* *}$ & 0.793 & $0.651^{* *}$ & 0.785 & $0.738^{*}$ & 0.769 \\
\hline Native American/other & 0.008 & 00.010 & 0.012 & 0.009 & 0.006 & 0.005 \\
\hline $\mathbf{N}$ & 10 & & 10 & & & \\
\hline
\end{tabular}

${ }^{*} \mathrm{p}<.05 ;{ }^{* *} \mathrm{p}<.01$ 
grade levels influence the differences between working and nonworking students.

As discussed previously, intense employment during the high school years has been linked with poor performance in school and with academic disengagement. Students who enter the labor force have been shown to have lower levels of achievement and to be more disengaged than their nonworking peers. For the most part, comparisons between working and nonworking students in the NELS: 88 10th- and 12th-grade panels corroborate this finding. Employed sophomores had slightly lower GPAs (3.01) than sophomores who were not employed (3.07), but scores on standardized tests were comparable. This is exactly what Schoenhals et al. (1998) found in their analysis of the determinants of 10th-grade employment using NELS:88. In contrast, however, employed seniors had somewhat higher test scores (52.32) than seniors who were not employed (51.59). ${ }^{4}$

With respect to academic engagement, employed sophomores were less attached and less committed to schooling than sophomores who did not hold paid jobs. On all measures of academic engagement, employed sophomores had been less engaged in the 8 th grade than their nonworking students. These differences are minimized somewhat when comparing employed seniors with those who did not work. Among seniors, working students were more likely than their nonworking peers to have skipped class and to have been tardy as sophomores. However, when in the 10th grade, both groups of students spent comparable amounts of time on homework and participating in extracurricular activities, and both were equally prepared for their classes.

Similar to the patterns detected for high school students, college students who took jobs during their first year of enrollment had had lower levels of achievement in high school and had been somewhat

\footnotetext{
4 This finding is most likely explained by the specification of employment as a binary status rather than a range of intensities. In their examination of the correlates of 10th-grade employment using NELS:88, Warren et al. (2000) found that standardized test scores were highest for those who worked 15 or fewer hours per week and lowest for those who worked more than 15 hours per week. Therefore, considering both groups as employed masks more nuanced differences among students who work at varying degrees of intensity.
}

less engaged in high school than first-year students who had focused solely on their studies. In this analysis, working college students had lower GPAs and lower test scores than nonworking college students. As high school sophomores, working college students had spent less time on their homework and less time participating in extracurricular activities than had nonworking college students. Therefore, at both the secondary and postsecondary level, students who did not excel in the classroom were apparently likely to enter the labor force.

Earlier I hypothesized that the composition of the college-going population would alter the academic profiles of working students. I predicted that students with the strongest orientation toward work and the least investment in their schooling would forgo college, and as a result, differences between working and nonworking college students regarding academic ability and academic engagement would be tempered or even eliminated. This prediction did not hold. Employed high school students were less oriented toward educational pursuits in the 10th grade than those who did not work; likewise, employed college students were less oriented toward educational pursuits than unemployed college students. Students with less favorable academic records may be testing the waters of postsecondary education while maintaining ties to the labor force in case they do not fare well in the college classroom. Additionally, low-performing students tend to come from families with few socioeconomic resources and for whom employment is an economic imperative.

With respect to demographic characteristics, differences between working and nonworking students are minimized as students age. The patterns for sex differences are not consistent. In the 10th grade, males are more likely than females to work; in the 12th grade, the reverse is true. Although research based on older data sets showed higher employment rates for adolescent males, Warren et al. (2000) note that more recent data sources reveal girls to be as likely to work as boys. No sex difference in rates of employment is detected in the first year of college. Students working in the 10th and 12th grades are more likely to be white and less likely to be Asian, Hispanic, or black. By the first year of college, 
however, employment status differentials remain only for whites and blacks: white first-year students are more likely than black first-year students to work.

Next, I examined patterns of academic performance, academic engagement, and socioeconomic support in conjunction with postsecondary pathways. In the adolescent employment literature, students with a weak orientation toward schooling and few socioeconomic resources invested the most time in their jobs. I anticipated similar patterns for first-year college students-those with poor academic records and those from low-SES families either will not enroll in college or will hold paid jobs if they do enroll. To test these predictions, I calculated the mean/ proportion for every student characteristic by each category of the postsecondary employment variable.
The findings are presented in Tables 5 through 8 . A significant $\mathrm{F}$ statistic indicates a significant difference between the groups' means or proportions.

Differences in academic performance by postsecondary pathways are shown in Table 5. Not surprisingly, those who did not enroll in college had significantly lower GPAs in the 8th grade and standardized test scores in the 10th grade than those who went on to college. Among college enrollees, those who did not acquire jobs during their first college year entered college with higher grades and test scores than those who worked part or all of their first college year. Those who worked a few months during the first year and those who worked the entire time they were enrolled did not differ on the measures of academic performance.

Table 5. Differences in academic performance by postsecondary pathways

\begin{tabular}{lccccc} 
& \multicolumn{4}{c}{ Postsecondary Pathways } \\
\cline { 2 - 6 } & No College & $\begin{array}{c}\text { Enroll and } \\
\text { Not Work }\end{array}$ & $\begin{array}{c}\text { Enroll and } \\
\text { Some Work }\end{array}$ & $\begin{array}{c}\text { Steady Enrollment } \\
\text { and Employment }\end{array}$ & F \\
\hline 8th-grademic Performance & $2.67^{\mathrm{bcd}}$ & $3.28^{\text {acd }}$ & $3.15^{\text {ab }}$ & $3.18^{\text {ab }}$ & $224.86^{* *}$ \\
10th-grade test scores & $46.26^{\mathrm{bcd}}$ & $55.33^{\text {acd }}$ & $53.75^{\text {ab }}$ & $54.15^{\text {ab }}$ & $334.26^{* *}$ \\
\hline
\end{tabular}

${ }^{*} \mathrm{p}<.05 ;{ }^{* *} \mathrm{p}<.01$

a Difference between No College significant at $p<.05$.

b Difference between Enroll and Not Work significant at $p<.05$.

c Difference between Enroll and Some Work significant at $\mathrm{p}<.05$.

$\mathrm{d}$ Difference between Steady Enrollment and Employment significant at $\mathrm{p}<.05$.

\section{Table 6. Differences in academic engagement by postsecondary pathways}

\begin{tabular}{lccccc} 
& \multicolumn{3}{c}{ Postsecondary Pathways } \\
\cline { 2 - 6 } Academic Disengagement & No College & $\begin{array}{c}\text { Enroll and } \\
\text { Not Work }\end{array}$ & $\begin{array}{c}\text { Enroll and } \\
\text { Some Work }\end{array}$ & $\begin{array}{c}\text { Steady Enrollment } \\
\text { and Employment }\end{array}$ \\
\hline Skipping class & $0.423^{\mathrm{bcd}}$ & $0.283^{\mathrm{a}}$ & $0.324^{\mathrm{a}}$ & $0.279^{\mathrm{a}}$ & $34.49^{* *}$ \\
\hline Tardiness & $0.781^{\mathrm{bcd}}$ & $0.710^{\mathrm{a}}$ & $0.718^{\mathrm{a}}$ & $0.709^{\mathrm{a}}$ & $11.06^{* *}$ \\
\hline Time spent on homework & $3.12^{\mathrm{bcd}}$ & $5.28^{\mathrm{acd}}$ & $4.77^{\mathrm{ab}}$ & $4.82^{\mathrm{ab}}$ & $116.80^{* *}$ \\
\hline $\begin{array}{l}\text { Time spent on } \\
\text { extracurricular activities }\end{array}$ & $2.31^{\mathrm{bcd}}$ & $4.55^{\mathrm{a}}$ & $4.16^{\mathrm{a}}$ & $4.13^{\mathrm{a}}$ & $71.80^{* *}$ \\
\hline Academic preparedness & $3.18^{\mathrm{bcd}}$ & $3.30^{\mathrm{a}}$ & $3.30^{\mathrm{a}}$ & $3.34^{\mathrm{a}}$ & $22.59^{* *}$ \\
\hline
\end{tabular}

${ }^{*} \mathrm{p}<.05 ;{ }^{* *} \mathrm{p}<.01$

a Difference between No College significant at $p<.05$.

b Difference between Enroll and Not Work significant at $p<.05$.

c Difference between Enroll and Some Work significant at $p<.05$.

$d$ Difference between Steady Enrollment and Employment significant at $p<.05$. 
Table 6 shows differences in academic engagement. Those who did not enroll in college were less likely to have invested in their school and in their coursework while in high school. However, among those who did enroll, student workers had had about the same level of academic engagement in the 10th grade as those who did not work. On only one measure, time spent on homework, did working and nonworking college freshmen differ: those who worked during the first year of college had spent significantly less time studying when in the 10th grade (4.77 hours a week for those who enrolled and worked at least 2 months but less than 8 months during their first enrollment spell, and 4.82 hours a week for those who enrolled and worked their entire first enrollment spell) than their nonworking counterparts (5.28 hours a week). While this difference meets the criteria for statistical significance, substantively speaking, the difference is not all that large. On average, nonworking college students had spent about a half hour more per week studying in the 10th grade than had working college students.

These findings reveal some nuances in the academic profiles of first-year college students. These descriptive findings suggest that employment in college is not entirely a by-product of a lack of interest in educational attainment. Those who balance the roles of student and worker have lower levels of academic performance, but they also have a history of being as engaged and committed to their schooling as those who do not hold jobs. A strong investment in paid work in high school may be linked with a process of academic disengagement, but these linkages appear to weaken in the college years.

As evidenced in Table 4, employment during the transition to college is related to socioeconomic resources within one's family. The ANOVA results in Table 7 further corroborate this finding. As expected, non-college-bound youth tend to come from families with low levels of income, have parents who did not attend college, and have a large number of siblings. Although employment in high school is more prevalent among those from advantaged families, the evidence from NELS: 88 suggests that students may take on jobs during their first year of college out of necessity-working students come from less-affluent families and have less-educated parents than nonworking students. Two reasons may explain this pattern. First, because low-income students have historically been averse to loan-based financial aid (Kane, 1999; Orfield, 1992), they may seek jobs as a means to deal with increasing college costs. Second, college-educated parents, knowing the difficulties associated with the adjustment to postsecondary life,

\section{Table 7. Differences in socioeconomic support by initial postsecondary pathways}

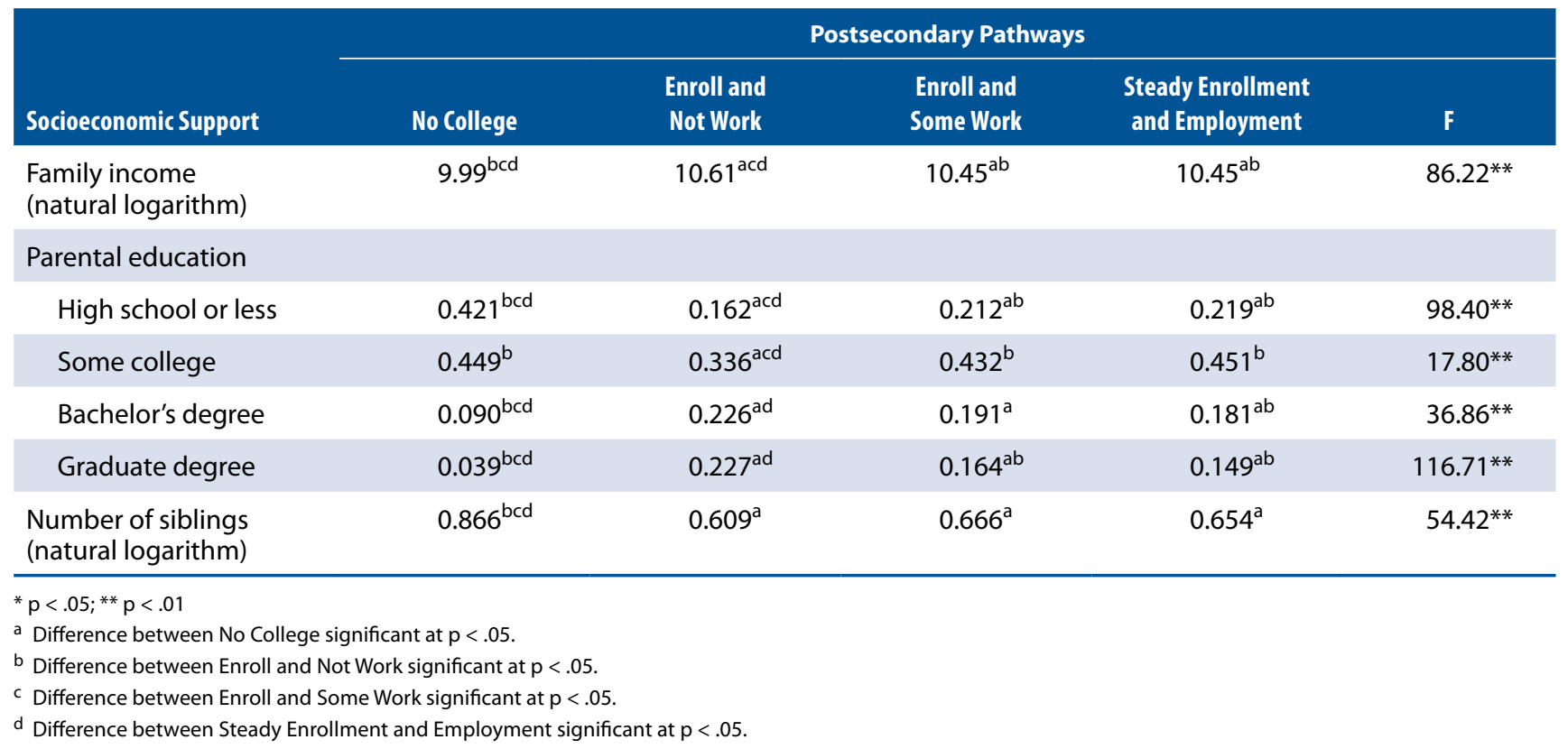


may limit their children's employment while they acclimate to college.

Finally, I examined the sex and racial/ethnic distributions using the four-category postsecondary pathway measure. The findings are shown in Table 8. In line with the bulk of research on postsecondary enrollment, I found that females are more likely to attend college than males, and whites and Asians are more likely to attend college than Hispanics and blacks. However, there are few noticeable differences in the employment rates of enrolled students. Although in high school male and white students are more likely to be employed than females and minorities, sex and racial/ethnic differences are muted during the transition to college. Relatively speaking, college students are a select group of individuals - highly motivated and academically prepared. As a consequence, demographic differences in employment may be less relevant.

Table 8. Differences in demographic characteristics by postsecondary pathways

\begin{tabular}{|c|c|c|c|c|c|}
\hline \multirow[b]{2}{*}{$\begin{array}{l}\text { Demographic } \\
\text { Characteristics }\end{array}$} & \multicolumn{5}{|c|}{ Postsecondary Pathways } \\
\hline & No College & $\begin{array}{l}\text { Enroll and } \\
\text { Not Work }\end{array}$ & $\begin{array}{l}\text { Enroll and } \\
\text { Some Work }\end{array}$ & $\begin{array}{c}\text { Steady Enrollment } \\
\text { and Employment }\end{array}$ & $\mathbf{F}$ \\
\hline \multicolumn{6}{|l|}{ Sex } \\
\hline Female & $0.439^{\mathrm{bcd}}$ & $0.517^{a}$ & $0.533^{\mathrm{a}}$ & $0.557^{\mathrm{a}}$ & $15.73^{* *}$ \\
\hline Male & $0.561^{b c d}$ & $0.483^{\mathrm{a}}$ & $0.467^{\mathrm{a}}$ & $0.443^{\mathrm{a}}$ & $15.73^{* *}$ \\
\hline \multicolumn{6}{|l|}{ Race/ethnicity } \\
\hline Asian/Pacific Islander & $0.024^{\mathrm{bcd}}$ & $0.057^{\mathrm{a}}$ & $0.046^{\mathrm{a}}$ & $0.045^{\mathrm{a}}$ & $12.91^{* *}$ \\
\hline Hispanic & $0.118^{\mathrm{bd}}$ & $0.081^{\mathrm{a}}$ & 0.096 & $0.087^{\mathrm{a}}$ & $4.49 * *$ \\
\hline Black, non-Hispanic & $0.149^{b c d}$ & $0.118^{\mathrm{ac}}$ & $0.085^{a b}$ & $0.092^{\mathrm{a}}$ & $8.44^{* *}$ \\
\hline White, non-Hispanic & $0.690^{\mathrm{bcd}}$ & $0.738^{\mathrm{a}}$ & $0.768^{\mathrm{a}}$ & $0.771^{\mathrm{a}}$ & $9.36^{* *}$ \\
\hline Native American/other & $0.019^{b c d}$ & $0.006^{\mathrm{a}}$ & $0.004^{\mathrm{a}}$ & $0.005^{\mathrm{a}}$ & $5.87^{* *}$ \\
\hline $\begin{array}{l}{ }^{*} \mathrm{p}<.05 ;{ }^{* *} \mathrm{p}<.01 \\
\text { a Difference between No Colle } \\
\mathrm{b} \text { Difference between Enroll an } \\
{ }^{2} \text { Difference between Enroll an } \\
\text { d }\end{array}$ & $\begin{array}{l}\text { it at } p<.05 \text {. } \\
\text { significant at } \\
\text { k significant }\end{array}$ & . & & & \\
\hline
\end{tabular}

\section{Discussion}

From adolescence into adulthood, individuals oscillate between their roles as students and workers, at times doing both. In the United States, the mean age at which students begin working for pay is 12 years (Mortimer, 2003). The average student goes on to complete at least some college coursework (US Department of Education, 2002). Therefore, the linkages between school and work extend beyond the early adolescent years into young adulthood. The majority of high school graduates go on to college, and the majority of college students maintain ties to the labor force. Thus, conceptualizing school and work as jointly linked pathways rather than separate transitions (i.e., "the transition to college" or "schoolto-work") is vital.

This analysis takes a small step in this direction by analyzing these linked pathways in the year immediately following high school graduation. Using nationally representative data on the high school class of 1992, I found that labor force participation during the transition from high school to college is relatively stable, highlighting the continuity of work patterns over the early life course. Those who work in high school tend to do so in the first year of college. Those who do not work tend to remain 
out of the labor force as college students. In the adolescent employment literature, moderate levels of employment have been linked with an orientation toward the future-students jointly invest in school and in work to enhance their resumes and to prepare themselves for the challenges and responsibilities of adulthood (Mortimer, 2003). My analysis shows that these trends continue into the postsecondary years. Moreover, recent research suggests that employment during the college years bodes well for individuals later on: young women who work while pursuing a postsecondary degree are less likely to be unemployed in their late 20s (Alon et al., 2001).

On the flip side, nonworkers in high school have very low odds of becoming student workers in their college years. Those who remain out of the labor force may do so for a number of reasons: they may be unemployable, may live in areas with weak labor markets, may face discrimination from employers, may wish to concentrate on their studies and on extracurricular activities, may lack a "taste for work," or may experience a combination of these. Whatever the reason, these students remain isolated from the economy, an important mainstream institution. That these students continue to stay out of the labor force during a pivotal time in the life course could lead to problems in seeking jobs once they complete their schooling.

Although we see a high degree of stability in the employment patterns of students from the high school years to the first year of college, do the academic and socioeconomic profiles of student workers follow suit? Several research teams using a range of data sets have shown that students who work, particularly at high levels of intensity, tend to have poorer academic credentials (Huang et al., 2001; Mortimer, 2003; Schoenhals et al., 1998; Warren et al., 2000). Given that those with the least investment in schooling and the strongest orientation toward work will forgo college, given that the academic climate is much more competitive at the postsecondary level, and given the large number of changes that accompany the transition to college, are college students who take on jobs during the first year of enrollment the low-achieving, academically disengaged students that we see working in high school?
The evidence from NELS:88 is mixed. Compared with nonworkers during their first year of college, students who worked during their first year of college had had lower grades and test scores and had spent less time on homework when in the 10th grade. However, working college students were equally likely as nonworking students to have shown up to class on time, to have participated in extracurricular activities, and to have been prepared for school when in the 10th grade. Based on the NELS:88 data, when compared with their nonworking peers, working college students are apparently less able academically but are equally engaged in their schooling.

Although very few data sets have information on the reasons students work, evidence from Mortimer's (2003) Minneapolis sample shows that the primary motive is personal consumption. Adolescents work mostly to purchase luxury items such as clothes, music, concert tickets, video games, and automobiles. Despite this present-oriented motive for working, Mortimer finds that the percentage of students working to save for their future education increases from 29.5 percent in the 9 th grade to 45.7 percent in the 12th grade. Therefore, as students age, their work is increasingly purposeful.

Although NELS:88 lacks direct information regarding the motives for employment in high school or in college, my analysis of socioeconomic resources provides indirect evidence that students hold jobs as a means to manage college expenses. In high school, working students tend to come from families with ample socioeconomic resources. My analysis shows that students who work during the first year of college come from families with limited socioeconomic resources. Students with less family income and a greater numbers of siblings likely work as a means to take care of tuition, room, board, books, and supplies-expenses that are typically not required for high school attendance. Taking the evidence from previous research alongside the findings from the NELS:88 cohort, the first year of college may represent a turning point in the work histories of employed students-work during this time becomes less a means for consumption and more of an economic necessity. 
Racial/ethnic differences in employment are not central to the research questions; however, analyses of NELS:88 shows that black students were overrepresented among nonworkers at both stages of schooling. As discussed earlier, this could be attributed to discrimination by employers, weak labor markets, few reliable contacts in the work force, poor academic credentials, or a combination of these. Whatever the cause, the fact remains that black youth have difficulty maintaining steady enrollment and employment in both high school and in college. Black youths historically have been disadvantaged in the labor market. They have a harder time finding work and are less likely to be employed than their white counterparts (Entwisle et al., 2000; Schoenals et al., 1998). This analysis documents that even high-achieving black youths attending college are less likely to work than their white peers. ${ }^{5}$ This could possibly hamper their employment prospects and enhance inequality in the labor market when they exit college.

A limitation to this analysis is that NELS:88 lacks a measure of weekly hours worked during the first year of college. This is unfortunate because much of the evidence from the adolescent employment literature shows that students who work at high levels of intensity tend to be more academically disengaged and have fewer socioeconomic resources than those who work at low levels of intensity. The dichotomous indicator of employment status is likely masking more nuanced differences among student workers. Another limitation is that the NELS: 88 cohort attended college over a decade ago, and thus there may be new dynamics driving enrollment-employment patterns. Given that college costs are higher today than they were in the early 1990s, I speculate that the relationship between student employment and socioeconomic resources may be even stronger today. Future research with comprehensive time-series data on more recent cohorts of youth will be needed to examine the patterning of employment intensity at later stages of schooling.

\section{Conclusion}

In closing, students leaving school face an economy that increasingly values ideas, communication, and technological know-how over traditional manual skills that dominated the labor force a half century ago. More than ever, employers seek out potential employees who have both sharp minds (as evidenced by a college degree) and sharp work skills (as evidenced by a solid work resume). Thus, those with the best labor market prospects when they exit school are those who have been successful in balancing the demands of being both a student and a worker.

Indeed, this research alongside others shows that this pathway is most conducive to making a successful transition to college, completing a college degree (Staff and Mortimer, 2007), and sustaining employment in adulthood (Alon et al., 2001). My analysis, however, also suggests that employment during the transition to college is not only a developmental bridge that prepares youth for the future, but it is also undertaken out of economic necessity. Because finances play a larger role in college than in high school, work may serve as a means for those with limited resources to sustain enrollment.

\footnotetext{
5 Recall that these data are based on samples of enrolled students and therefore contain a relatively privileged population of minority youth. Those who are not enrolled for long periods of time and miss the administration of the survey, those who do not enroll in college, and those who are in correctional facilities are not included in these data.
} 


\section{References}

Alon S, Donahoe D, Tienda M. The effects of early work experience on young women's labor force attachment. Soc Forces. 2001;79:1005-34.

Bozick R. Making it through the first year of college: the role of students' economic resources, employment and living arrangements. Sociol Educ. 2007; 80:261-85.

Bozick R, DeLuca S. Better late than never? Delayed enrollment in the high school to college transition. Soc Forces. 2005;84:531-4.

Carr RV, Wright JD, Brody CJ. Effects of high school work a decade later: evidence from the National Longitudinal Survey. Sociol Educ. 1996;69:66-81.

College Board. Trends in college pricing. Washington, DC: College Board; 2002.

D'Amico R. Does employment during high school impair academic progress? Sociol Educ. 1984;57:152-64.

Ehrenberg RG, Sherman DR. Employment while in college, academic achievement, and postcollege outcomes: a summary of results. J Hum Resour. 1987;22:1-23.

Entwisle DR, Alexander KL, Olson LS. Early work histories of urban youth. Am Sociol Rev. 2000;65:279-97.

Entwisle DR, Alexander KL., Olson LS, Ross K. Paid work in early adolescence: developmental and ethnic patterns. J Early Adolesc. 1999;19:363-88.

Furr SR, Westefeld JS, McConnell GN, Jenkins JM. Suicide and depression among college students: a decade later. Prof Psychol Res Pr. 2001;32:97-100.

Greenberger E, Steinberg LD. When teenagers work: the psychological and social costs of adolescent employment. New York: Basic Books; 1986.

Huang L, Pergamit M, Shkolnik J. Youth initiation in the labor market. Mon Labor Rev. 2001;18-24.

Jacobs JA, King RB. Age and college completion: a life history analysis of women aged 15-44. Sociol Educ. 2002;75:211-30.

Kane TJ. The price of admission: rethinking how Americans pay for college. Washington, DC: Brookings Institution Press; 1999.
Keithly DC, Deseran F. Households, local labor markets, and youth labor force participation. Youth Soc. 1995;26:463-92.

Manning WD. Parenting employed teenagers. Youth Soc. 1990;22:184-200.

Marsh HW. Employment during high school: character building or a subversion of academic goals? Sociol Educ. 1991;64:172-89.

Meyer RH, Wise DA. High school preparation and early labor force experience. In: Wise DA, editor. The youth labor market problem: its nature, causes, and consequences. Chicago: University of Chicago Press; 1982. p. 277-347.

Mortimer JT. Working and growing up in America. Cambridge, MA: Harvard University Press; 2003.

Mortimer JT, Finch MD, Dennehy K, Lee C, Beebe T. Work experience in adolescence. J Voc Educ Res. 1994;19:39-70.

Oettinger GS. Does high school employment affect high school academic performance? Ind Labor Relat Rev. 1999;53:136-51.

Orfield G. Money, equity, and college access. Harv Educ Rev. 1992;72:337-72.

President's Science Advisory Committee. Youth: the transition to adulthood. Chicago: University of Chicago Press; 1974.

Rosenbaum JE. Beyond college for all: career paths for the forgotten half. New York: Russell Sage Foundation; 2001.

Schoenhals M, Tienda M, Schneider B. The educational and personal consequences of adolescent employment. Soc Forces. 1998;77:723-62.

Staff J, Mortimer JT. Educational and work strategies from adolescence to early adulthood: consequences for educational attainment. Soc Forces. 2007;85:1169-1194.

StatCorp. Stata statistical software: release 7.0 user's guide. College Station, TX: Stata Corporation; 2001.

Steel L. Early work experience among white and non-white youths: implications for subsequent enrollment and employment. Youth Soc. 1991;22:419-47. 
Steinberg LD, Cauffman E. The impact of employment on adolescent development. Ann Child Dev. 1995;11:131-66.

Stern D, Nakata Y. Characteristics of high school students' paid jobs and employment experience after graduation. In: Stern D, Eichorn D, editors. Adolescence and work: influences of social structure, labor markets, and culture. Chicago: University of Chicago Press; 1989. p. 189-223.

Stevenson W. The relationship between early work experience and future employability. In Adams AV, Mangum GL, editors. The lingering crisis of youth unemployment. Kalamazoo, MI: W.E. Upjohn Institute for Employment Research; 1978. p. 93-124.
US Department of Education, National Center for Education Statistics. Digest of education statistics 2002. Washington, DC: US Government Printing Office; 2002.

US Department of Education, National Center for Education Statistics. How families of low- and middle-income undergraduates pay for college: full-time dependent students in 1999-2000. Washington, DC: US Government Printing Office; 2003.

Warren JR, LePore PC, Mare R. Employment during high school: consequences for students' grades in academic courses. Am Educ Res J. 2000;37:943-69 


\section{Appendix}

\section{Academic Performance, Engagement, and Socioeconomic Support Measures: National Education Longitudinal Study of 1988}

\begin{tabular}{|c|c|c|}
\hline Student Characteristic & Description & Interview \\
\hline \multicolumn{3}{|l|}{ Academic Performance } \\
\hline Grade point average & $\begin{array}{l}\text { Continuous measure based on student-reported grades in English, mathematics, } \\
\text { science, and social studies }\end{array}$ & 8th grade \\
\hline Test scores & Continuous composite of standardized reading and math tests & 10th grade \\
\hline \multicolumn{3}{|l|}{ Academic Engagement } \\
\hline Skipping class & $\begin{array}{l}\text { Dichotomous measure based on how often students reported cutting or skipping } \\
\text { class in the first half of the current school year } \\
\begin{array}{l}1=\text { skip/cut class } \\
0=\text { never }\end{array}\end{array}$ & 10th grade \\
\hline Tardiness & $\begin{array}{l}\text { Dichotomous measure based on student reported tardiness in the first half of the } \\
\text { current school year } \\
\begin{array}{l}1=\text { tardy } \\
0=\text { on-time }\end{array}\end{array}$ & 10th grade \\
\hline Time spent on homework & $\begin{array}{l}\text { Continuous measure based on student-reported weekly hours spent on homework } \\
\text { outside of school }\end{array}$ & 10th grade \\
\hline $\begin{array}{l}\text { Time spent on } \\
\text { extracurricular activities }\end{array}$ & $\begin{array}{l}\text { Continuous measure based on student-reported weekly hours spent on school- } \\
\text { sponsored extracurricular activities }\end{array}$ & 10th grade \\
\hline Academic preparedness & $\begin{array}{l}\text { Scale based on three questions asked to 10th graders on how often they come to } \\
\text { class without pencil or paper, books, or homework done } \\
\text { Higher value = more prepared }\end{array}$ & 10th grade \\
\hline \multicolumn{3}{|l|}{ Socioeconomic Support } \\
\hline Family income & Natural logarithm of total family income in 1987, parent reported & 8th grade \\
\hline Parental education & $\begin{array}{l}\text { Categorical measure of parent's reported highest level of education: high school or } \\
\text { less, some college, bachelor's degree, graduate/ professional degree or higher }\end{array}$ & 10th grade \\
\hline Number of siblings & $\begin{array}{l}\text { Natural logarithm of student-reported number of siblings in the same household; } \\
\text { including adopted, step-, and half siblings }\end{array}$ & 10th grade \\
\hline
\end{tabular}





\section{Acknowledgments}

This research has benefited from the comments and suggestions of Karl Alexander, Nan Astone, Stefanie DeLuca, Richard Miech, and Steven Plank. All responsibility lies with the author alone. 
RTI International is an independent, nonprofit research organization dedicated to improving the human condition by turning knowledge into practice. RTI offers innovative research and technical solutions to governments and businesses worldwide in the areas of health and pharmaceuticals, education and training, surveys and statistics, advanced technology, democratic governance, economic and social development, energy, and the environment.

The RTI Press complements traditional publication outlets by providing another way for RTI researchers to disseminate the knowledge they generate. This PDF document is offered as a public service of RTI International. More information about the RTI Press can be found at www.rti.org/rtipress. 